\title{
THE EFFECT OF PHYSICAL FITNESS TO CHANGE HUMAN HEALTH AND IMPROVE THE QUALITY OF LIFE
}

\author{
OEFEITO DA APTIDÃO FISICA PARA MUDARA SAÚDE HUMANA EMELHORARA QUALIDADEDEVIDA
}

Original Article

ARTIGO ORIGINAL

EL EFECTO DE LA APTITUD FÍSICA PARA CAMBIAR LA SALUD HUMANA Y MEJORAR LA CALIDAD DE VIDA

Artículo Original

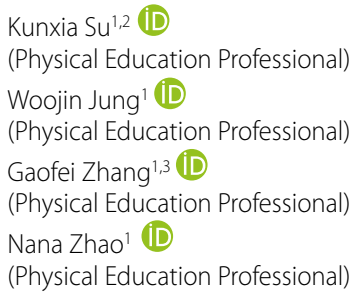

(Physical Education Professional) Woojin Jung' (D)

(Physical Education Professional) Gaofei Zhang ${ }^{1,3}$ (ID)

(Physical Education Professional) Nana Zhao' (ID)

(Physical Education Professional)

1. College of Art and Physical Education, Gangneung-Wonju National University, Gangneung, Korea.

2. Department of Public Teaching, Zhongyuan Institute of Science and Technology, Zhengzhou, Henan, China.

3. Physical Education College, Zhoukou Normal University, Zhoukou, Henan, China.

\section{Correspondence:}

Nana Zhao

College of Art and Physical

Education, Gangneung-Wonju

National University, Gangneung,

210600, Korea.

skxlyn1314@163.com

\begin{abstract}
Introduction: People need to strengthen their bodies through leisure sports to prevent diseases. Physical fitness exercise is conducive to maintaining a good physical and mental state and establishing a good interpersonal relationship. Exercise can keep people happy. Object: According to the actual needs of people's physical fitness exercises, this article uses the correlation analysis method to carry out an empirical analysis on the effect of physical fitness exercises on the quality of life. Method: The paper puts forward a model based on indicators combined with correlation analysis by constructing a hypothetical model of the effect of physical fitness exercise. We analyzed the reasons and influencing factors of people participating in physical fitness exercises. Results: The influencing indicators of people's participation in sports to improve the quality of life are gender, age, and disposable income. Conclusion: People playing sports can enhance the quality and quality of life. Level of evidence Il; Therapeutic studies - investigation of treatment results.
\end{abstract}

Keywords: Physical Fitness; Exercise ; Life Quality; Interpersonal Relations.

\section{RESUMO}

Introdução: As pessoas precisam fortalecer seus corpos por meio de esportes de lazer para prevenir doenças. O exercício de aptidão física contribui para a manutenção de um bom estado físico e mental e para o estabelecimento de um bom relacionamento interpessoal. Oexercício pode manter as pessoas felizes. Objetivo: De acordo com as reais necessidades de exercícios de aptidão física das pessoas, este artigo utiliza o método de análise de correlação para realizar uma análise empírica sobre o efeito dos exercícios de aptidão física na qualidade de vida. Método: O artigo propõe um modelo baseado em indicadores combinados com análise de correlação por meio da construção de um modelo hipotético do efeito do exercício de aptidão física. Analisamos os motivos e fatores que influenciam as pessoas que participam de exercícios de aptidão física. Resultados: Os indicadores que influenciam a participação das pessoas no esporte para melhorar a qualidade de vida são gênero, idade e renda disponivel. Conclusão: Pessoas que praticam esportes podem melhorar a qualidade de vida. Nível de evidência ll; Estudos terapêuticos - investigação dos resultados do tratamento.

Descritores: Aptidão Física; Exercício Físico; Qualidade de Vida; Relações Interpessoais.

\section{RESUMEN}

Introducción: Las personas necesitan fortalecer su cuerpo a través de deportes recreativos para prevenir enfermedades. El ejercicio físico favorece el mantenimiento de un buen estado físico y mental y el establecimiento de una buena relación interpersonal. El ejercicio puede hacer felices a las personas. Objeto: De acuerdo con las necesidades reales de los ejercicios de aptitud física de las personas, este artículo utiliza el método de análisis de correlación para realizar un análisis empírico sobre el efecto de los ejercicios de aptitud fisica en la calidad de vida. Método: El trabajo propone un modelo basado en indicadores combinados con análisis de correlación mediante la construcción de un modelo hipotético del efecto del ejercicio físico. Analizamos los motivos y factores de influencia de las personas que realizan ejercicios de acondicionamiento físico. Resultados: Los indicadores que influyen en la participación de las personas en el deporte para mejorar la calidad de vida son el género, la edad y la renta disponible. Conclusión: las personas que practican deportes pueden mejorar la calidad de vida. Nivel de evidencia ll; Estudios terapéuticos: investigación de los resultados del tratamiento.

Descriptores: Aptitud Física; Ejercicio Físico; Calidad de Vida; Relaciones Interpersonales.

\section{INTRODUCTION}

With the increase of age, the functions of various organs of the elderly begin to decline to various degrees, and body tissues are gradually weakening. Their physical resistance is much lower than before. Various diseases follow, and the incidence rate is also increasing. In participating in sports, the elderly can increase their physical fitness, have a healthier body, and prevent the occurrence of some diseases. However, in sports, they need to pay attention to the flexibility of exercise, promote the development of the whole body, and make the body harmonious. Psychology has reached the best state.' With society's progress, the elderly can look for new social roles and make their lives more diverse while participating in leisure sports. 
An essential part of social behavior is sports behavior, which is to pursue a particular goal and have a particular interpersonal relationship with others. Some scholars said that the most significant influence factors on college students'sports are campus, family, social media, venues, etc. If there is a lack of sports equipment, it will also cause college students to be unwilling to participate in sports or seriously reduce their enthusiasm for participation. Some scholars have researched the cognition of sports behavior. ${ }^{2}$ This article combines the needs of the sports of the elderly. It uses a multi-index analysis method to comprehensively study the impact of the elderly's leisure exercise on improving the quality of life. Through empirical analysis, it can be found that the elderly's leisure exercise can enhance their lives.

\section{METHOD}

\section{Model establishment}

Table 1 is the measurement matrix. The content of the evaluation is leisure variables and quality of life. According to the research content of this article, the indicators of leisure behavior of the elderly are proposed from the following five aspects: leisure attitude, leisure supervision satisfaction, leisure Participation status, satisfaction with use of leisure resources, use of leisure resources.

Among the above five indicators, the subjective indicators of leisure mainly include the following three aspects, taking people as the central variable: leisure attitude, leisure participation status, and leisure satisfaction. The objective indicators of leisure mainly include the following two aspects, taking place as the central variable: satisfaction with the use of leisure resources and the use of leisure resources.

Table 1. Measurement matrix of the relationship between leisure variables and quality of life.

\begin{tabular}{c|c|c}
\hline $\begin{array}{c}\text { Comment } \\
\text { content }\end{array}$ & Objective criteria & Competent standard \\
\hline People & Casual participation & Casual attitude \\
\cline { 3 - 3 } Place & Use of leisure resources & Leisure satisfaction \\
\cline { 3 - 3 } & & Environmental quality satisfaction \\
\hline
\end{tabular}

After constructing the indicators, this article points out:The process of leisure participation will directly affect the leisure attitude of the elderly in the city. Leisure satisfaction also directly affects the leisure attitude of the urban elderly. Life satisfaction will also positively affect the leisure satisfaction of urban elderly. Satisfaction with the use of leisure resources directly affects the leisure resources of the urban elderly. The satisfaction of life has a positive impact on the satisfaction of the urban elderly in the use of leisure resources. ${ }^{3}$ And then get the hypothetical structure model of Figure 1. From this figure, we can see the relationship between the leisure behavior of the urban elderly and the subjective quality of life.

\section{Analysis method combined with multiple indicators}

This article's questionnaire data is analyzed and counted by using SPSS18.0 software, combined with actual needs, and pointed out the research method of multi-index analysis.

\section{Multi-index analysis of variance}

The so-called variance analysis refers to the difference in the test variable's mean under a particular influencing factor. ${ }^{4}$ This article points out that multi-index analysis of variance is based on such hypothesis testing, mainly through the following methods and steps:

Firstly, create the null hypothesis:

$$
H_{0}: \mu_{1}=\mu_{2}=\ldots=\mu_{r}
$$

The above formula $H_{1}=\mu_{i}(i=1,2, \ldots, r)$ is not entirely equal. $\mu_{i}$ represents the average value of the variable under the i-th level. Different influencing factors will not make the mean value of the variable have a significant change.

Secondly, create statistics:

$$
F=\frac{M S B}{M S E}=\frac{S S B(r-1)}{S S E(n-r)}
$$

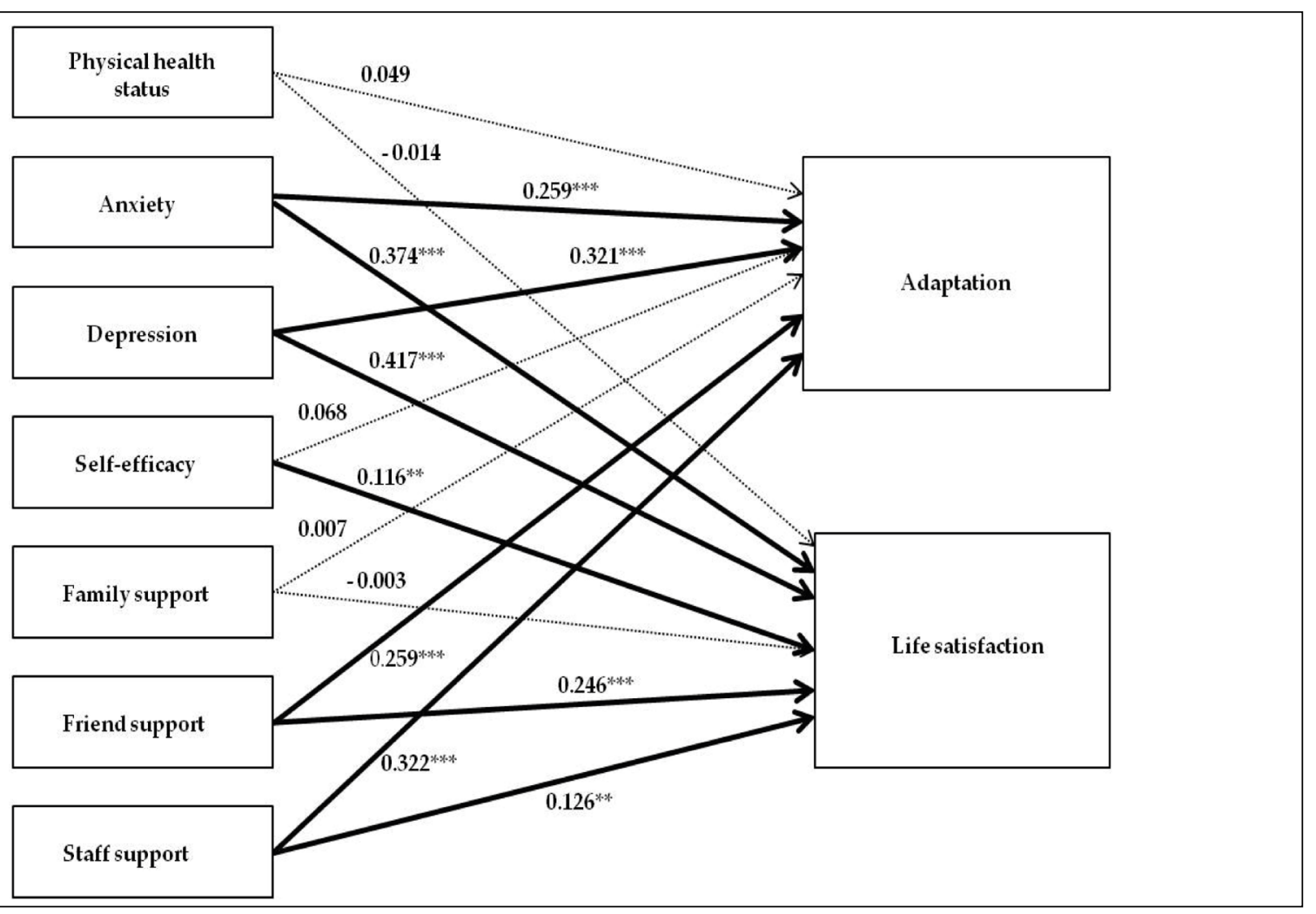

Figure 1. Hypothetical structural model. 
Assuming that the original conditions are met, then the F distribution is obeyed, and the degree of freedom is $(r-1, n-r)$.

Thirdly, by analyzing the null hypothesis and sample data, it is possible to solve the F statistic and the corresponding $P$ two values.

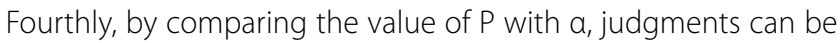
made based on the null hypothesis. ${ }^{5}$ (Figure 2 )

\section{Parameter test}

After analyzing the variance of multiple indicators, the parameters need to be detected. (Figure 3)

\section{Correlation analysis among multiple indicators}

This article uses Pearson's simple correlation coefficient to analyze and verify the correlation of multiple indicators. The specific formula is as follows:

$$
r=\frac{\sigma_{x y}^{2}}{\sigma_{x} \sigma_{y}}
$$

The above formula $\sigma_{x y}^{2}$ represents the covariance between the variables $x$ and $y, \sigma_{x}$ and $\sigma_{y}$ represent the standard deviation between the variables $x$ and $y$. Testing the Pearson correlation coefficient makes the following assumption: the correlation coefficient of the two populations is zero. ${ }^{6}$ Through mathematical principles, we can know: if the null hypothesis is true, then the statistics obey the t distribution, and its degree of freedom is $(n-2)$.

$$
t=\frac{r \sqrt{n-1}}{\sqrt{1-r^{2}}}
$$

\section{RESULTS}

This article uses a multi-index analysis method to empirically analyze the survey results, mainly analyzing the following three attributes: gender, age, and income.

\section{Correlation analysis of gender attributes}

Table 2 shows the correlation analysis results of the participation rates of urban elderly of different genders in different leisure activities. ${ }^{7}$

From Table 2, we can know that older people of different genders will have differences in entertainment leisure activities, and the probability

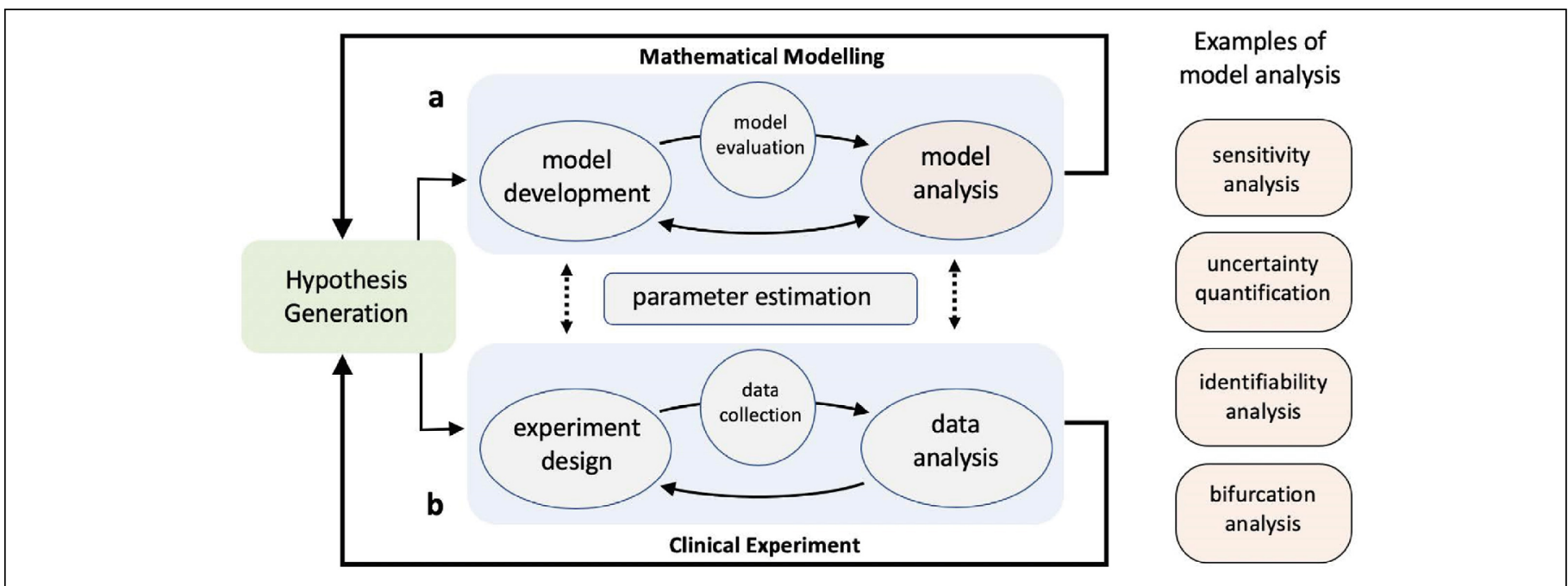

Figure 2. Multi-index analysis of variance algorithm flow.

Phase 1: Problem modeling

(1): Deterministic quantitative
performance model
(2): Quantitative performance
model under uncertainty
(3): Quantitative performance
model for flexibility<smiles>[C]1CCCC1</smiles>

Phase 4: Sensitivity analysis

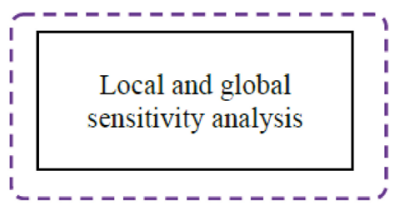

Phase 2: Screening procedure

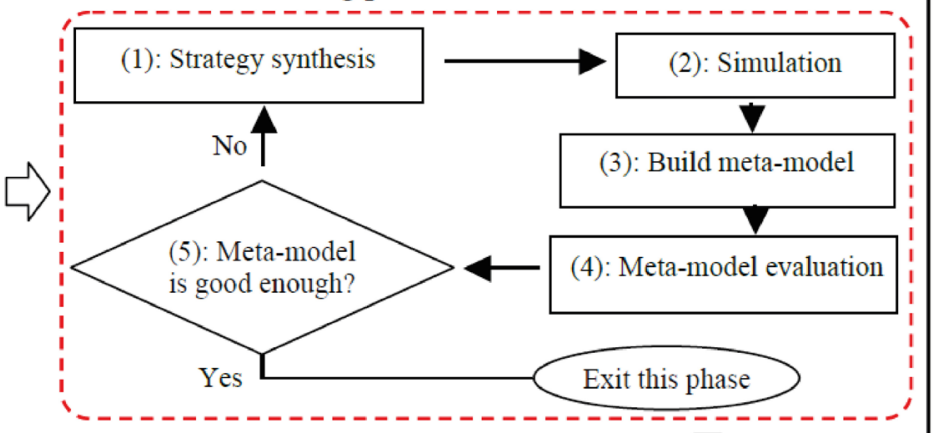

Phase 3: Multi-criteria decision-making

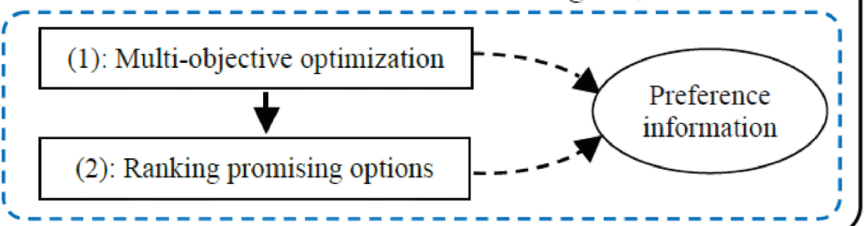

Figure 3. Multi-index variance parameter test process. 
of correlation is 0.05 , showing significant differences. However, there is no significant difference in social leisure activities, pleasure leisure activities, sports leisure activities, and recreational leisure activities. This is the difference between the frequency of participating in entertainment leisure activities. ${ }^{8}$ Older urban people of different genders show significant differences in the frequency of leisure resource use. ${ }^{9}$ This is because the probabilities of cultural leisure resources and social leisure resources are both less than 0.05 . Based on the indicators' average value, male urban older people use these two resources more than females.

\section{Correlation analysis of age attributes}

Table 3 shows the correlation analysis results of participation types at different ages. It can be known from Table 3 that all types of leisure activities have a correlation of less than 0.05 , which means that there are significant differences in the participation of the elderly in urban areas of all ages in leisure activities. Through the mean value, it can be understood that when older people of different ages participate in dynamic leisure activities, such as sports, social activities, etc., the frequency will be inversely proportional to their age. The frequency of participating in static or some recreational activities is proportional to age.

Table 2. Correlation analysis results of participation frequency of different genders.

\begin{tabular}{c|c|c|c|c|c|c}
\hline \multirow{2}{*}{$\begin{array}{c}\text { Types of leisure } \\
\text { activities }\end{array}$} & \multicolumn{2}{|c|}{ Mean } & \multicolumn{2}{c|}{ variance analysis } & \multicolumn{2}{c}{$\begin{array}{c}\text { Correlation } \\
\text { analysis }\end{array}$} \\
\cline { 2 - 7 } & Male & Female & F & Sig. & t & Sig. (2-t) \\
\hline Recreational & 3.11 & 3.08 & 0.614 & 0.414 & 1.428 & 0.124 \\
\hline Emotional & 3.02 & 3.28 & 1.218 & 0.219 & 1.106 & 0.198 \\
\hline Entertainment & 3.65 & 2.96 & 42.94 & 0 & 7.157 & 0 \\
\hline Sports & 3.18 & 3.04 & 1.146 & 0.21 & 1.712 & 0.074 \\
\hline Social & 3.46 & 3.42 & 0.128 & 0.626 & 0.615 & 0.418 \\
\hline
\end{tabular}

Table 3. Correlation analysis results of participation types at different ages.

\begin{tabular}{c|c|c|c|c|c|c}
\hline \multirow{2}{*}{$\begin{array}{c}\text { Types of leisure } \\
\text { activities }\end{array}$} & \multicolumn{5}{|c|}{ Mean } & \multicolumn{2}{c}{ Variance analysis } \\
\cline { 2 - 7 } & $\mathbf{6 0 - 6 9}$ & $\mathbf{7 0 - 7 9}$ & $\mathbf{8 0 - 8 9}$ & $\mathbf{9 0 - 9 9}$ & $\mathbf{F}$ & $\mathbf{P}$ \\
\hline Recreational & 2.64 & 2.82 & 3.15 & 3.52 & 47.52 & 0 \\
\hline Emotional & 3.1 & 3.17 & 3.24 & 2.15 & 24.68 & 0 \\
\hline Entertainment & 3.16 & 3.02 & 2.62 & 2.04 & 40.21 & 0 \\
\hline Sports & 3.12 & 3.11 & 3.01 & 2.61 & 12.15 & 0 \\
\hline Social & 3.94 & 3.28 & 3.29 & 2.86 & 21.48 & 0 \\
\hline
\end{tabular}

The correlation $P$ values of various types of leisure resources are less than the significance level of 0.05 , which means that different ages have significant differences in the use of various types of leisure resources. The most significant restriction is the distance of leisure activities for the elderly in the city. The radius of activity of the elderly will decrease with the increase of age, and they are more inclined to exercise in front of their homes.

\section{Correlation analysis of income attributes}

The frequency of leisure activities of the elderly will vary greatly depending on the income level of the elderly. Recreational leisure activities will be expressed in the indicators' average value, which will be significantly affected. Low-income older people prefer recreational leisure activities, mainly because of the impact of economic conditions. Most of their income is spent on clothing, food, housing, and transportation. Enough money is spent on leisure activities but listening to the radio or watching TV can meet low-income urban older adults' needs.

Different leisure resources have different frequency of use, and there are significant differences between the income of the elderly and the use of sports resources. The level of education of the urban elderly can largely determine their income level. The higher the income of the elderly, the higher the average value of cultural leisure resources indicators. At the same time, the income of fitness resource users is between 0 and 1,000 yuan. The health-preserving resource use group is at the two levels of 1001 3500 yuan, and if the income is higher than 3500 yuan, there is no higher frequency of resource use.

\section{CONCLUSION}

For the elderly, leisure sports have many advantages. For example, it can stimulate the elderly's love for sports and make their bodies healthier. After retirement, the elderly can have a more prosperous life circle and make their spare life more abundant. This article mainly combines the needs of the elderly for sports. It uses multiple indicators to analyze the impact of the elderly's leisure sports on the quality of life. Through empirical research, it is found that the three attributes of gender, age, and income will affect the participation of the elderly. Frequency of leisure sports. All in all, leisure activities can improve the quality of life of urban older adults.

All authors declare no potential conflict of interest related to this article

AUTHORS' CONTRIBUTIONS: Each author made significant individual contributions to this manuscript. Kunxia Su and Nana Zhao: writing and performing surgeries; Woojin Jung and Gaofei Zhang: data analysis and performing surgeries, article review and intellectual concept of the article.

\section{REFERENCES}

1. Werneck AO, Silva DR, Malta DC, Souza-Júnior PR, Azevedo LO, Barros MB, et al. Changes in the clustering of unhealthy movement behaviors during the COVID-19 quarantine and the association with mental health indicators among Brazilian adults. Translational Behavioral Medicine. 2021 [cited 202111 Jun];11(2): 323-31. Available from: https://www.arca.fiocruz.br/handle/icict/45436

2. Zhang X, Chen S, Gu X. Ethnic disparities in mental health and movement behaviors during childhood: examining the longitudinal developmental patterns.J Racial Ethn Health Disparities. 2020;7(6):1249-57.

3. Weil AR. Tackling social determinants of health around the globe. Health Aff (Millwood). 2020;39(7):1118-21.

4. Żuk P, Żuk P, Lisiewicz-Jakubaszko J. The anti-vaccine movement in Poland:The socio-cultural conditions of the opposition to vaccination and threats to public health. Vaccine. 2019;37(11):1491-4.

5. Albertsen MN, Natvik E, Råheim M. Patients' experiences from basic body awareness therapy in the treatment of binge eating disorder -movement toward health: a phenomenological study. J Eat Disord. 2019;7:36.
6. Cuijpers P, Veen SC, Sijbrandij M, Yoder W, Cristea IA. Eye movement desensitization and reprocessing for mental health problems: a systematic review and meta-analysis. Cogn Behav Ther. 2020;49(3):165-80.

7. Liguori G, Gallé F, Di Onofrio V, Valeriani F, Romano Spica V; WDPP, Working Group Doping Prevention Project; GSMS-SItI, Working Group on Movement Sciences for Health, Italian Society of Hygiene Preventive Medicine and Public Health. Higher education on physical activity and sport: The Movement Sciences graduate as a resource to promote healthy lifestyles in the National Health System. Ann Ig. 2019;31(6):642-8.

8. Goode AD, Hadgraft NT, Neuhaus M, Healy GN. Perceptions of an online 'train-the-champion' approach to increase workplace movement. Health Promot Int. 2019;34(6):1179-90.

9. Abdullahi A, Van Criekinge T, Umar NA, Zakari UU, Truijen S, Saeys W. Effect of constraint-induced movement therapy on persons-reported outcomes of health status after stroke: a systematic review and meta-analysis. Int J Rehabil Res. 2021;44(1):15-23. 